\title{
Public and community libraries in Limpopo Province, South Africa: prospects and challenges
}

\author{
Solomon Tsekere Bopape ${ }^{1}$, Maoka Dikotla², Matlala Mahlatji ${ }^{3}$, \\ Morongoenyane Ntsala ${ }^{4}$ and Makgahlela Lefose ${ }^{5}$ \\ solomon.bopape@ul.ac.za ORCID: 0000-0003-3389-2378 \\ Maoka.Dikotla@ul.ac.za ORCID: 0000-0002-6699-6782 \\ Rachel.Mahlatji@ul.ac.za ORCID: 0000-0002-3504-4260 \\ Morongoe.Ntsala@ul.ac.za ORCID: 0000-0001-9362-5445 \\ Lefose.Makgahlela@ul.ac.za ORCID: 0000-0003-1433-2527
}

\begin{abstract}
Received: 1 April 2019
Accepted: 29 April 2021
\end{abstract}

\begin{abstract}
Acceleration of access to information through the provision of library and information services to rural communities is recognised with much appreciation by the library and information services (LIS) sector in South Africa. As more community libraries are being built and public libraries refurbished, it becomes important to investigate whether these library and information service centres meet the information needs of the communities they serve. This paper is a report of a qualitative and quantitative study that investigated the prospects and challenges for public and community libraries in Limpopo Province, South Africa. For data collection, a questionnaire with closed-and open-ended questions was distributed to staff in selected public and community libraries in Limpopo Province to complete. The study revealed that most of the challenges to the provision of access to library and information services in Limpopo Province are related to outdated and irrelevant materials, small buildings, lack of databases, insufficient internet access and connectivity, as well as lack of materials for people living with disabilities. It seems, therefore, that there are information needs that cannot be met by even newly established and improved libraries and information service centres. Studies of this nature in the country will make it possible to propose possible solutions and strategies for the future improvement of LIS, especially for future implementation of the national LIS policy for South Africa.
\end{abstract}

Keywords: Public libraries, information services, community information, rural communities, challenges; Limpopo Province

\section{Introduction}

The existence of public and community libraries in every community is not a privilege, but an essential requirement for access to information for community members. Public and community libraries exist to provide facilities for lifelong learning, educational materials for school children, reference materials for post-matric students, access to government services, as well as other information required to fulfil daily information needs. Uzoigwe and Chinwendu (2017) highlighted that many families that are living in rural areas and who cannot afford to obtain information resources when their basic needs such as food, water, light and shelter cannot be met, depend solely on public and community libraries to obtain information that can address educational, informational and recreational needs. Real, Bertot and Jaeger (2014) confirmed that public and community libraries are the only point of access to information in many rural communities, while Goodman (2008: 513) pointed out that "community libraries are built to serve the needs of rural populations outside the reach of standard information services". Therefore, the pronouncement that public or community libraries play a fundamental role in fostering social and economic development of people, especially those living in rural environments, cannot be overemphasised. Due to the value attached to the existence and use of public and community libraries, governments across the world are committed to prioritising them, investing more in them, and recognising their potential as strategic interventions and role players in advancing economic and social development of citizens.

The South African government demonstrates this determination through energies directed towards improved subsidy and political support for libraries. After an era of neglect, public and community libraries have been the beneficiaries of substantial additional funding from the government in a programme "to transform urban and rural public library infrastructure, facilities and services" (Patel, Skarzynski \& Nassimbeni 2015: 1). The government of South Africa initiated a conditional

1. Solomon Bopape is Head, Department of Communication, Media and Information Studies, University of Limpopo, South Africa

2. Maoka Dikotla is Senior Lecturer: Programme of Information Studies, University of Limpopo, South Africa

3. Matlala Mahlatji is Lecturer: Programme of Information Studies, University of Limpopo, South Africa

4. Morongoenyane Ntsala is Lecturer: Programme of Information Studies, University of Limpopo, South Africa

5. Makgahlela Lefose is Lecturer: Programme of Information Studies, University of Limpopo, South Africa 
grant through the Department of Sports, Arts and Culture (DSAC), allocated to all the nine provinces in South Africa, "to redress the past imbalances and inequalities in the library and information services (LIS) sector by improving and refurbishing existing services, establishing new libraries and purchasing new books for public libraries" (Department of Arts and Culture and National Library of South Africa 2016). The conditional grant targets previously disadvantaged communities with the "objective of providing and improving library infrastructure and services to meet community needs and to promote a culture of reading" (Patel, Skarzynski \& Nassimbeni 2015: 1). Furthermore, the National Council of Libraries and Information Services (NCLIS), in conjunction with the DSAC, produced the Library and Information Services Transformation Charter in 2014. The purpose of the LIS Transformation Charter is to define the challenges facing the LIS sector in South Africa and to "provide a clear framework of principles and mechanisms for effecting the changes needed for [libraries] to contribute to the elimination of illiteracy and inequality, and the building of an informed and reading nation" (Nkondo et al. 2014: 5). Moreover, DSAC commissioned the South Africa Public Library and Information Services Bill (2012) with the purpose of legislating public library norms and standards for LIS at a national level in South Africa. In addition, the government launched the LIS National Policy in March 2018. To produce this policy, the members of the task team consulted widely both inside and outside the LIS sector; they consulted with LIS academics and specialists, consumers of library and information services, the community, and political leaders. The task team "met individuals and groups from each of the nine provinces, ... received numerous formal submissions and ... made a particular effort to engage with both policy implementers and policy beneficiaries" (Nkondo, Hart \& Nassimbeni, 2018: iv).

All these measures are steps in the right direction in gradually addressing the findings uncovered in previous studies on the state of LIS in South Africa (National Education Policy Investigation 1992, Arts and Culture Task Group 1995, Van Helden and Lor 2002). In these studies, the issues of policy, governance and funding are at the top of the list of challenges that are faced by LIS organisations in the country which were, in one way or another, inherited from the apartheid era and a period of capital desertion in the first period of the new South Africa (Nkondo et al. 2014). Furthermore, there are grant funds from The Carnegie Corporation of New York that are used by various libraries in South Africa to increase access to the internet and to purchase library materials, thereby strengthening the collections of these libraries. These purchases include those published by South Africans locally and abroad, thus building the collection of contemporary indigenous fiction and non-fiction in all eleven official South African languages (Nkondo et al. 2014).

Ralebipi-Simela (2015: 9) made mention of the Mzanzi Libraries Online (MLO) Project courtesy of the Bill \& Melinda Gates Foundation grant that is enhancing the commendable work already being done by community libraries. The MLO Project, a conditional grant, provides pilot libraries an opportunity to redefine their services based on free internet access to information, introduction and incorporation of new technologies in existing and new services, re-designed spaces and technology infrastructure, and training and development of library end-users and staff based on identified training needs (Matolong 2016). Efforts of this nature are set to guarantee more access to, and uninterrupted use of, internet services in community and public libraries across the country. Moreover, these efforts by the government are steps in the right direction to bridging the digital divide and equalising access to information in rural communities (Russell \& Huang 2012).

Following plausible establishment and improvement of numerous public and community libraries, supported by distribution of the DSAC conditional grant as well as the introduction of the MLO Project and other initiatives working towards improved access to information for the rural communities, there is a need to establish if there are any problems and challenges that public and community libraries still face. Patel, Skarzynski and Nassimbeni (2015: 1) expressed the view that there was a lack of empirical evidence to demonstrate the extent to which additional funding and support were achieving the desired objectives of "empowering communities, promoting reading and improving literacy rates". In the same vein, Real, Bertot and Jaeger (2014: 6) expressed the feeling that "rural public libraries have been relatively understudied when compared to public libraries as a whole", while Stilwell (2011, in Mnkeni-Saurombe and Zimu, 2015: 47) reported that "research on public libraries and social cohesion is constrained due to lack of comprehensive information". This study serves as an attempt to fill this gap by investigating the challenges that new or improved public and community libraries encounter in their quest to advance the social and economic status of the people of Limpopo. Accordingly, the objectives of the study are:

- to establish the library resources and facilities provided in public and community libraries in Limpopo Province;

- to identify any information needs that cannot be met by public and community libraries in Limpopo Province;

- to establish the perspectives of librarians regarding the changes that they would like to see in these libraries; and

- to discover obstacles that impede the provision of library and information services in Limpopo Province.

Revealing these challenges could perhaps serve as a point of departure in the implementation of the LIS policy in South Africa, and as a platform for proposing possible solutions and strategies for the future improvements of LIS in the country. In Limpopo Province, in particular, public and community libraries operate in both urban (city) and rural (village) 
settlements. However, "the greater percentage of the population in the province is based in rural areas where poverty, illiteracy and unemployment are prevalent" (Mokgaboki 2002: 78). Mojapelo (2017) noted that the legacy of inequitable apportionment for public and community libraries during the era of apartheid South Africa is still visible in the entire province. It is therefore assumed that the Limpopo's Department of Sport. Arts and Culture - through its library and information services unit - plays a vital role in promoting public libraries and archives in the province through the improvement of access to library facilities and the promotion of a sustainable reading culture (Bopape et al. 2017). It would however be appropriate to reveal the challenges encountered in both the newly established community libraries and the improved or refurbished public libraries.

\section{Literature Review}

The literature review on the provision of access to information in South Africa through public and community libraries reflects the past injustices, the present prospects and the challenges experienced. The past is characterised by the complexities that are related to the apartheid government, fuelled by the deliberate under-resourcing of library and information service facilities in the black communities. The present prospects are seen through the determination shown by the post-apartheid government to remove inequalities in the provision of library and information services to the people of South Africa. However, it appears there are challenges that still hinder adequate provision of library and information services in South Africa.

\subsection{The past}

It has been persistently noted that the public LIS sector in South Africa is rooted in its colonial past, which has led to insights into the sector being "derived from the public library backgrounds of other countries that are based on Anglo-American and Eurocentric library practices" (Bopape et al. 2017: 2). A concept of a community library has existed subsequent to the previous political dispensation when some communities, especially rural ones, were barred from accessing public library services (Mostert 1998, Hicken 2004). Mostert (1998: 73) explained that, in an effort to counteract deprivation of access to public libraries, "innovative services in the form of Community Resource Centres were introduced to serve the communities with reading materials and advice to local citizens". Dent (2006) also made mention of the community information centres which were established in countries like Botswana, Ghana and Tanzania and other countries in Africa whereby local homes or churches provided space for people to sit and read. These community centres were supported financially and administratively by the communities themselves and by non-governmental organisations. It was only after the introduction of the new democratic government that public libraries were faced with the task of delivering information services to communities as a whole, not only "to the well-educated, literate, and the middle-class members of the community" (Mostert 1998: 73). Lor, van Helden and Bothma (2005) reported that after 1994, funding for Community Resource Centres was diverted to the new legitimate government which resulted in many of the Community Resource Centres being abandoned while some were combined with existing local public libraries. This amalgamation resulted in the development of the practice of referring to public libraries as community libraries. Though there are norms for community libraries and for public libraries (Mostert, 1998, Aicheson 2006), in this study, these two terms ('community libraries' and 'public libraries') are used interchangeably.

\subsection{Prospects}

Mnkeni-Saurombe and Zimu (2015: 41) believed that, for the South African government to develop informed inhabitants who are able to participate in the global and knowledge economy, there is a need for transformation in urban and rural community library infrastructure, facilities and services, with special emphasis on underprivileged communities. The provision of LIS to the majority of the people, especially those living in rural areas, has become crucial. The time has arrived to create community libraries that have a vibrant role to play as an essential resource for satisfying the educational and informational needs of a community, as well as improving the quality of life for these communities. Mojapelo (2017: 412) noted that public and community libraries have a role to play in the "attainment of the goals of the National Development Plan for the development and advancement of peoples' lives".

Public libraries and community libraries are Community Information Centres, so they should provide people with community information. Community information is information that enables individuals to overcome daily challenges related to their survival and existence (Feather \& Sturges 2003). 'Survival information' is that information related to health, housing, income, legal protection, economic opportunities, political rights, civil rights and citizen action needed for effective participation as individuals or as members of a group in the social, political, legal and economic process (Donohue 1976 in Chatterjee 2017: 280). Public and community libraries are also an important means to provide services through the creation of social capital (Hart 2007, Russell \& Huang 2012, Johnson 2012, Johnson 2015, Adams 2018). Hart (2007: 14) defined 
social capital as "the stocks of social trust, norms and networks that a community can draw on to solve common problems". Eryaman (2010: 136) cites Evan and Boyte (1993) who refer to libraries as

free spaces in which young people can meet, talk about their problems and experiences, reflect on their rights, work to create change in their communities, as well as to allow disadvantaged people to learn a new self-respect, a deeper and more assertive group identity, public skills, and values of cooperation and civic virtue.

Social capital is also used to describe interactions and networks among people living in the same community to build functional relationships and social units. Adams (2018: 16) emphasised that public and community libraries play a role in the creation of social capital by "connecting individuals and the community with their library services and programmes and promoting the staff-patron interactions that attempt to create patron trust in the library". For public and community libraries to play a role in social capital, there is a need to redesign their physical space and include rooms where various groups in the community can meet and interact (Johnson 2015). Hernon and Mathews (2012: 144) made mention of the public or community libraries that adapt to the changing environments in which they operate, whereby they serve as "multipurpose community centres offering business information services, tax assistance, safe havens for children after school, and even places where immigrants can learn English". Mohan (2002: 133) mentions another component of a community library called "local information", which is

information appropriate and useful to the community, including a calendar of local events, courses and other educational opportunities, and basic information concerning government agencies, local organisations, fraternal groups, and clubs".

Mohan (2002) also identified "neighbourhood information or trans-local information, such as information about medical specialists, employment opportunities in the neighbourhood" as an important dimension of public or community libraries. Today, a community information service is not only delivered to the people through printed books, but also through increased access to computers and the internet. Therefore, public and community libraries have a substantial role to play in providing access to technology-enhanced services, as well as in improving information and communication technology literacies of library users (Mojapelo 2017). Hart (2010: 83) noted that "providing internet connectivity to the developing world will help them realise goals for health, education, employment and poverty reduction". Public and community libraries are, therefore, identified as institutions that should provide computer and internet services and resources to their users. Free availability and access to computers and the internet in public and community libraries is seen as a necessity for members of the community.

\subsection{Challenges}

The provision of public and community library and information services to users has been a problem since they were neglected by the government in the apartheid era. For this reason, Jiyane, Mugwisi and Moyane (2016: 59) acknowledged that "public libraries face a plethora of challenges most particularly in the information age". Hildreth and Sullivan (2015) suggested that expanding access to information is one of the challenges that public and community libraries face in today's environment. The LIS Transformation Charter (Nkondo et al. 2014) indicates that the challenges encountered by public and community libraries in South Africa are inherited from the apartheid government and a period of funding neglect in the first decade of democracy. The challenges mentioned in the LIS Transformation Charter "also relate to infrastructural deficits, human resource demands and operational difficulties" (Nkondo et al. 2014: 55). Similarly, the findings of the study conducted by Uzoigwe and Chinwendu (2017) revealed poor funding, poor staffing, poor remuneration of library staff, lack of up-to-date collections, poor infrastructure, and un-automated library services in public libraries in Enugu State, Nigeria.

Therefore, despite the conditional grant by the DSAC, public and community libraries still face budget-related challenges (Mnkeni-Saurombe 2010, Mojapelo 2017). Due to lack of funding, other key success factors such as space, resources, electricity, internet connectivity, equipment and security are also affected. Hernon and Mathews (2012: 144) cautioned that "inadequate funding for libraries may possibly result in reduced opening hours, staff positions eliminated, acquisition budget reduced, branch libraries closed for one or two days or even permanently". Accordingly, Troknya (2014) opined thus: "Many libraries in rural areas are at a crossroads where they find themselves in a financial situation that does not allow them to advance and they often must reduce to fewer hours and/or less accommodations for their patrons".

Gichohi, Onyancha and Dulle (2017: 21) stated that "public libraries are also community information centres, hence well-placed to serve the small-scale business community". As part of provision of community information, public and community libraries play a substantial role in the fiscal emancipation of the people they serve by "providing services such as free and public internet access, space, education, question answering, and materials on many business-related subjects" 
(Bishop, Mehra \& Partee II 2016: 37). Gichohi, Onyancha and Dulle (2017:21) conducted a study on the provision of library and information services by public libraries to small-scale business enterprises in Kenya and found that the provision of such information is "in a desolate state owing to inadequate business collections, lack of sufficient information, communications technology facilities, poor awareness of business information service, a poor reading culture, and weak collaborations of public library with stakeholders".

Numerous studies have shown that most of the people who use public libraries and community libraries today are postschool students who are registered for degrees or diplomas with universities, FET colleges and open distance learning institutions. Conducive space for studying, writing assignments, accessing and consulting reference materials, as well as accessing and retrieving information from the internet are some of the services and resources that this user group seeks and pursues in public and community libraries (Raseroka 1986, Hart 2010, Wishart 2012, Hart \& Nassimbeni 2013). This gives rise to the question of whether public and community libraries are in a good position to serve the information and resources needs of this user group or not. Students studying in public and community libraries may not have full access to electronic resources and databases. One of the reasons public and community libraries are underused "could be that they do not offer what people need or want" (Hart 2010: 82).

\section{Methodology}

To investigate whether the challenges and problems discussed above still prevail in public and community libraries in Limpopo Province, librarians employed in those libraries were asked about: (a) their respective library resources and facilities they provide in their libraries; (b) the existence of any information needs that could not be satisfied by their libraries; (c) their perspectives regarding the changes that they would like to see in their libraries; and (d) obstacles that impede the provision of LIS in their libraries. The study adopted both quantitative and qualitative research approaches using a questionnaire, with both closed- and open-ended questions to address both research approaches. The research population for this study were public librarians employed in selected public and community libraries from all the five districts of Limpopo Province.

According to the National Library of South Africa's Directory of Public and Community Libraries in South Africa (2012: 68), there were ninety-four public and community libraries in the five districts of Limpopo Province at the time of collecting data for this study. For researchers to reach the targeted libraries, a convenience sampling method was used to focus on public and community libraries that were easily accessible. To solicit accurate and rich information, a purposive sampling method was used by distributing the questionnaires only to the library staff members who were found in public and community libraries that were visited. The questionnaires were delivered to each of the selected libraries on 22-23 November 2016 and collected a week later on 1-2 December 2016. Completed questionnaires were collected from the libraries and forty-three (86\%) out of fifty distributed questionnaires were completed. Table 1 shows the libraries from where the researchers collected the data.

Table 1 Participating libraries according to district

\begin{tabular}{|c|c|c|c|c|}
\hline Capricorn District & Vhembe District & Mopani District & Greater Sekhukhune District & Waterberg District \\
\hline $\begin{array}{l}\text { Senwabarwana Library } \\
\text { Lebowakgomo Library } \\
\text { Mogwadi Library } \\
\text { Polokwane Library } \\
\text { Moletji Library } \\
\text { Mankweng Library }\end{array}$ & $\begin{array}{l}\text { Xihlovo Library } \\
\text { Makhado Public Library } \\
\text { Thulamela Library }\end{array}$ & $\begin{array}{l}\text { Ba-Phalaborwa Public Library } \\
\text { Tzaneen Public Library } \\
\text { Letsitele Library }\end{array}$ & $\begin{array}{l}\text { Ga-Phaahla Library } \\
\text { Jane Furse library } \\
\text { Marble-Hall Public Library }\end{array}$ & Mokopane Public Library \\
\hline
\end{tabular}

\section{Results and discussion}

This section covers the presentation and discussion of the findings relating to the participants' demographic profiles, available public and community library resources and services, information needs that could not be met, what changes the participants would like in these libraries, and the challenges that they experience.

\subsection{Respondents' profile}

The study intended to ascertain the demographic distribution of the respondents: their age, qualifications, years of service, and the number of staff in each library. Results in Table 2 show that nineteen $(44 \%)$ of the respondents were aged between 36 and 40 years, fifteen (35\%) between 26 and 35 years, four (9\%) below 25 years, another four (9\%) between 41 and 55 years, while only one was aged above 56 years. Van der Walt and du Plessis (2010) noted that very little research focuses on the age diversity of information professionals. Regarding qualifications, twenty-three (53\%) respondents indicated their highest qualification as degrees, fifteen (35\%) matriculants, and five (12\%) held diplomas from technical and/or vocational colleges. No one had a master's degree or any other equivalent qualification. When asked how many years respondents 
have been working in those libraries, three $(7 \%)$ stated that they had been working for less than a year, nine $(21 \%)$ from one to three years, eight (19\%) from four to six years, five (12\%) from seven to ten years, while eighteen (42\%) had been working for more than ten years. Table 2 further reveals that respondents indicated that there were $133(44 \%)$ professional librarians and eighty-nine (29\%) administrative staff, while eighty $(27 \%)$ were temporary workers (interns, volunteers) in all the libraries combined.

Table 2 Profile of librarians

\begin{tabular}{llc}
\hline & Variable & Frequency \\
\hline Age $(\mathbf{N}=\mathbf{4 3})$ & Below 25 years & $4(9 \%)$ \\
& $26-35$ years & $15(35 \%)$ \\
& $36-40$ years & $19(44 \%)$ \\
Highest qualification $(\mathbf{N}=\mathbf{4 3 )}$ & $41-55$ years & $4(9 \%)$ \\
& Above 56 years & $1(3 \%)$ \\
\hline & Matric & $15(35 \%)$ \\
& Degree & $23(53 \%)$ \\
Years of experience $(\mathbf{N}=\mathbf{4 3 )}$ & Masters & $0(0)$ \\
& Diploma (Technical/TVET) & $5(12 \%)$ \\
\hline & Less than 1 year & $3(7 \%)$ \\
& $1-3$ years & $9(21 \%)$ \\
& $4-6$ years & $8(19 \%)$ \\
& $7-10$ years & $5(12 \%)$ \\
& More than 10 years & $18(42 \%)$ \\
\hline
\end{tabular}

\subsection{Library resources and facilities}

Respondents were asked to indicate facilities and resources provided in their libraries. As shown in Table 3, all forty-three $(100 \%)$ respondents indicated that their libraries provide children's books/services, forty-two $(98 \%)$ indicated that they provide computers with internet access, thirty-three (74\%) newspapers, thirty-two (74\%) magazines, thirty-four (39\%) reference materials, while fourteen (33\%) indicated that they were providing interlibrary loans, followed by nine $(21 \%)$ providing databases. Databases and interlibrary loan services are the least available resources and services that libraries provide. It is the responsibility of every public library to meet the needs of children and youth (Gill 2001: 134). With regards to the computers and internet access, Mojapelo (2020: 265) wrote that "in this era of information age and information economy, easy and instant access to the internet are inevitabilities for socio-economic deployment". Newspapers in public libraries also keep users informed of new developments in the society (Osborne 2004: 51, Pacy 2014).

Table 3 Library resources and facilities

\begin{tabular}{lcc}
\hline Variable & Yes & No \\
\hline Children book/services & $43(100 \%)$ & $0(0 \%)$ \\
Databases & $9(21 \%)$ & $34(79 \%)$ \\
Computers with internet access & $42(98 \%)$ & $1(2 \%)$ \\
Computers for typing & $41(95 \%)$ & $2(5 \%)$ \\
Wi-Fi & $32(74 \%)$ & $7(16 \%)$ \\
Newspapers & $33(78 \%)$ & $9(21 \%)$ \\
Magazines & $32(74 \%)$ & $11(26 \%)$ \\
Reference materials & $34(79 \%)$ & $9(2 \%)$ \\
Interlibrary loans service & $14(33 \%)$ & $29(67 \%)$ \\
\hline
\end{tabular}




\subsection{Information needs that could be met}

Respondents were asked whether there are information needs that are not met by the library and, if so, which needs they were. Twenty-eight $(78 \%)$ respondents indicated that there were information needs that could be met by the library, while only eight $(22 \%)$ indicated that there were no information needs that could not be met by their libraries. The reasons advanced for the existence of information needs that cannot be met included:

- Lack of databases: Ten respondents stated that their libraries had no databases and online resources to enhance their collection and broaden their searches. One complained that "the library still uses the manual system for providing library services, for example, there is no online catalogue to facilitate interlibrary loans".

- Limited study materials were also mentioned, and it was indicated that there were too few resources, so often many users had to share a book. One respondent wrote that, "there are fewer books and most of the times users have to argue over them. Sometimes users do not find what they want".

- Irrelevant and outdated library collection: Fewer librarians indicated that library books were outdated. This phenomenon is observable in libraries that were modelled on Western patterns of librarianship. Public libraries in developing countries are generally stocked with materials that are foreign, out-of-date and unrelated to the information needs and interests of the people expected to read them (Abu, Grace \& Carroll 2011, Okiy 2003), contrary to the statement from the International Federation of Library Associations and Institutions (IFLA) Public Libraries Section (n.d.: 1), that "collections and services [of public libraries] are developed to meet the current, emerging and future needs of the local community and include print and electronic resources".

- No services for people living with disabilities. Nine librarians stated that they could not meet the information needs of people living with disabilities. Some stated there were no computers and braille materials. Some stated that even the physical structure of the library was not user-friendly to people in wheelchairs. One librarian specified that there was no Job Access With Speech (JAWS) software to allow the visually impaired to access and use computers. Therefore, the needs of people living with disabilities are compromised.

- Lack of reading space: Three librarians indicated that the libraries were too small, so there was no reading space. This meant that most of the users who visited the library for a quiet reading space were not catered for.

\subsection{What would be changed in the libraries?}

Table 4 shows what the respondents would change at their libraries if given the chance to do so. The question was meant to identify areas that needed improvement in the libraries. The majority of the respondents 'strongly agree' that they would change a number of things in their libraries. Thirty-one (72\%) respondents strongly agreed that they would change to large buildings, twenty-six (60\%) to current and up-to-date materials, twenty-five (58\%) to buy more computers, and twenty-four (56\%) to increase internet connectivity. Mojapelo and Fourie (2014: 140) revealed that teacher librarians at schools in Limpopo Province commented about "library buildings, furniture, funds, computers and access to the internet" which are among some of the things needed to support fully-fledged library services. Latimer (2007) suggested that, when changing library and information services, the planning and design of library buildings to achieve attractive, efficient and futureoriented new library spaces should be taken into consideration.

Table 4 What would be changed in the library?

\begin{tabular}{lcccc}
\hline What would be changed & $\begin{array}{c}\text { Strongly } \\
\text { disagree }\end{array}$ & Disagree & Agree & $\begin{array}{c}\text { Strongly } \\
\text { agree }\end{array}$ \\
\hline Larger building & $4(9 \%)$ & $0(0 \%)$ & $6(14 \%)$ & $31(72 \%)$ \\
Current and up-to-date materials & $1(2 \%)$ & $3(7 \%)$ & $10(23 \%)$ & $26(60 \%)$ \\
Extend opening hours & $12(28 \%)$ & $5(12 \%)$ & $10(23 \%)$ & $8(19 \%)$ \\
Reduce opening hour & $31(72 \%)$ & $9(21 \%)$ & $5(12 \%)$ & $6(14 \%)$ \\
Expand reference collection & $3(7 \%)$ & $3(7 \%)$ & $13(30 \%)$ & $22(51 \%)$ \\
Provide handicapped access & $4(9 \%)$ & $5(12 \%)$ & $15(35 \%)$ & $18(42 \%)$ \\
Buy more computers & $3(7 \%)$ & $2(5 \%)$ & $10(23 \%)$ & $25(58 \%)$ \\
Increase internet connectivity & $3(7 \%)$ & $1(2 \%)$ & $10(23 \%)$ & $24(56 \%)$ \\
Acquire more children 's literature & $2(5 \%)$ & $8(19 \%)$ & $14(33 \%)$ & $16(37 \%)$ \\
Acquire materials in home languages & $3(7 \%)$ & $3(7 \%)$ & $15(35 \%)$ & $17(40 \%)$ \\
Conduct community needs analysis & $2(5 \%)$ & $3(7 \%)$ & $18(42 \%)$ & $17(40 \%)$ \\
\hline
\end{tabular}

\subsection{Challenges encountered in the provision of library services}

Librarians were asked what problems were encountered that hinder or prevent them from meeting the needs of their users. This was an open-ended question, and, for the purpose of data analysis, the responses were categorised into themes. The 
challenges that were identified by the thirty-three respondents, who stated that they encountered challenges in providing library services to their users, included the following:

- Lack of community awareness: Most of the respondents strongly agreed that there was a lack of community awareness about the library. One librarian indicated that they did have business-related materials, but small, medium and micro enterprises (SMMEs) were not visiting the library. Reid and Howard (2016: 188) stated that although the "topic of community engagement in public libraries has been researched in urban public library systems, little research explores community engagement in rural library systems". It has been revealed by Goulding (2009: 37) that "provision of community library and information services have been quite effective at involving local people in the simpler forms of community engagement, such as surveying their opinions and consulting them on a range of issues".

- Staff training and development: The respondents indicated that there are no workshops to equip them with the necessary skills or knowledge to serve people living with disabilities. Respondents also indicated that sometimes they are not permitted to attend workshops to enhance their knowledge. This shows that there is a need for training and development of public library staff similar to in Meyer (2010) and Mthembu (2019). Hart (2004) emphasised the need for public and community librarians to become more proactive because of the transformation in education. Mostert and Vermeulen (1998: 21) wrote thus:

Staff should be trained to develop skills that will enable them to become pro-active agents of information transfer. They should learn how to anticipate needs, in order to act even before such needs are expressed. They should also be taught how to go out into the community, using knowledge gained to bring the library to the people, instead of adopting a sit-and-wait attitude.

- Library infrastructure: The majority of respondents indicated lack of or little reading space available in their libraries. A few respondents indicated that some libraries were not fully accessible to the public because of their geographic location. The results also show that there was a lack of library systems available for information searches. There were no online facilities, such as online public catalogues or online databases to search for information. One respondent complained about the lack of library collaboration systems, so they could not participate in interlibrary loans.

- Competent and qualified library staff: A few respondents indicated a lack of competent and qualified library staff as the main challenge. As shown in Table 2, the libraries employ both administrative staff and professional staff. In addition, there are volunteers. Table 2 also revealed that the majority $(60 \%)$ of staff held a degree as their highest qualification. The study conducted by Fischer (2015) found that the most challenging managerial issue for small town and rural public libraries throughout the United States of America was staffing.

- Management and administration processes: Some respondents indicated that they sometimes received conflicting instructions from both DSAC and their municipality. This challenge was also highlighted by MnkeniSaurome and Zimu (2015) in that the provincial and local governments struggle to reach an amicable solution with respect to the policy on the management and funding of community libraries. This has, therefore, also affected provision of public and community library services. Another factor included budget issues. One respondent wrote, "Libraries are receiving less budget wherein sometimes there would not be transport for outreach projects". Still on the same issue, a few respondents mentioned that they were not aware of some policies, such as a procurement policy, so some important materials were not bought for the library. Challenges regarding procurement processes seem to be a widespread problem in the South African public sector and government departments (Ambe \& Badenhorst-Weiss 2012, Mantzaris 2014).

- Library resources: Most respondents indicated that their libraries had old, outdated collections. In cases where there was a current collection, the collection was not relevant to the information needs of the users. There is a need to ensure that libraries know the information needs of their users (Borlund \& Pharo 2019, Harbo \& Hansen 2012). One respondent stated that they did not have books on music or the arts, while the majority of users who visited the library wanted materials in those fields.

\section{Conclusion and recommendations}

One of the limitations of the physical spaces of public and community libraries visited is that they are still designed for the traditional role and capability of public and community libraries in South Africa. There is a need to concentrate more on developing concepts beyond this traditional role. Perhaps, it is for this reason that most of the librarians working in those public and community libraries and information services in Limpopo Province agree that there are still information needs that could be met by these libraries. They cited irrelevant, outdated and limited study materials; lack of online databases; and lack of library materials, services for the disabled and reading space as some of the factors that prevented these libraries from meeting certain information needs. These deficiencies were confirmed when they were asked about what they wished to see changed in their libraries. Their wishes are to have larger library buildings and current, up-to-date library materials. As far as challenges that they encountered in delivering library and information services, they were very 
concerned about the lack of community awareness about the libraries and the lack of proper training programmes for library staff. Lack of training programmes for staff results in incompetent and unqualified library staff, which was also mentioned as one of the challenges encountered in the provision of library and information services. Lastly, the librarians raised concern about the conflicting instructions from the provincial Department of Sports, Arts and Culture and the municipality, as well as unclear procurement processes followed by the Department. These challenges should be an issue of concern for all the provinces when the South African LIS sector is gearing towards the implementation of the LIS policy.

\section{Acknowledgement}

This paper reports part of the findings of a study sponsored by the South African Library and Information (SALI) Trust. Every year, the SALI Trust offers a number of grants in the field of Library and Information Services work in South Africa. One such grant is the research and development of librarianship and information work, which was awarded to the Programme of Information Studies, University of Limpopo in 2016.

\section{References}

Abu, R., Grace, M. and Carroll, M. 2011. The Role of the rural public library in community development and empowerment. The International Journal of the Book, 8(2): 63-74. DOI:10.18848/1447-9516/CGP/v08i02/36863.

Adams, L.E. 2018. The contribution of library programmes at the Emfuleni library and information services in creating social capital to reduce poverty. PhD Thesis. University of South Africa. [Online]. http://uir.unisa.ac.za/bitstream/handle/10500/25176/thesis_adams_le.pdf?sequence=3\&isAllowed=y (04 November 2020).

Aicheson, J. 2006. Experiments in the provision of rural community libraries in South Africa: the family literacy project's initiatives. Innovation, 32: 94-109.

Ambe, I.A. and Badenhorst-Weiss, J.A. 2012. Supply chain management challenges in the South African public sector. African Journal of Business Management, 6(44): 11003-11014.

Arts and Culture Task Group. 1995. Report on libraries and information services subcommittee. Pretoria: National Library of South Africa.

Bishop, B.W., Mehra, B. and Partee II, R.P. 2016. The role of public libraries in small business development. Public Library Quarterly, 35(1): 37-48.

Bopape, S., Dikotla, M.A., Mahlatji, M.R. Ntsala, M.J. and Makgahlela, L.A. 2017. Identifying the information needs of public library services users in Limpopo Province. South African Journal of Library and Information Science, 83(1): 110.

Borlund, P. and Pharo, N. 2019. A need for information on information needs. Information Research Suppl., 24(4). [Online]. http://www.informationr.net/ir/24-4/colis/colis1908.html (19 April 2020).

Chatterjee, A. 2017. Elements of information organisation and dissemination. Amsterdam: Chandos Publishing.

Dent, V.F. 2006. Modelling the rural community library: characteristics of the Kitengeza library in rural Uganda. New Library World, 107(1/2): 13-30.

Department of Arts and Culture and National Library of South Africa. 2016. The state of conditional grant funded libraries in South Africa. Pretoria: Department of Arts and Culture and National Library of South Africa.

Eryaman, M.Y. 2010. The public library as a space for democratic empowerment: Henry Giroux, radical democracy and border pedagogy. In Critical theory for Library and Information Science: exploring the social from across the disciplines. Leckie, G.J., Given L.M. and Buschman, J.E., Eds. California: Libraries Unlimited.

Feather, J. and Sturges, P. 2003. International Encyclopedia of Information and Library Science, $2^{\text {nd }}$ ed. London and New York: Routledge.

Fischer, R.K. 2015. Rural and small town library management challenges. Public Library Quarterly, 34(4): 354-371.

Gichohi, P.M., Onyancha, B. and Dulle, F. 2017. Provision of business information services by public libraries to smallscale business enterprises. Mousaion, 35(3): 1-21.

Gill, P. 2001. The public library service: IFLA/UNESCO guidelines for development. IFLA Publications 97. [Online]. https://www.ifla.org/files/assets/hq/publications/archive/the-public-library-service/publ97.pdf (27 March 2019).

Goodman, V.F.D. 2008. Rural library services: historical development and modern-day examples from West Africa. New Library World, 109(11/12): 512-532.

Goulding, A. 2009. Engaging with community engagement: public libraries and citizen involvement. New Library World, $110(1 / 2): 37-51$.

Harbo, K. and Hansen, T.V. 2012. Getting to know library users' needs: experimental ways to user-centred library innovation. LIBER Quarterly, 21(3/4): 367-385.

Hart, G. 2004. Public libraries in South Africa: agents or victims of educational change? South African Journal of Library and Information Science, 70(2): 110-120.

Hart, G. 2007. Social capital: a fresh vision for public libraries in South Africa? South African Journal of Library and Information Science, 73(1): 14-24.

Hart, G. 2010. New vision, new goals, new markets? Reflections on a South African case study of community libraries. South African Journal of Library and Information Science, 76(2): 81-90. 
Hart, G. and Nassimbeni, M. 2013. From borders and landscape to ecosystem: reconfiguring library services to meet the needs of South African youth. South African Journal of Libraries and Information Science, 79(1): 13-21.

Hernon, P. and Matthews, J.R. 2012. Future views of public libraries. In Reflecting on the future of academic and public libraries. P. Hernon and J.R. Matthews, Eds. London: Facet Publishing. 141-150.

Hicken, M. 2004. To each according to his needs: public libraries and socially excluded people. Health Information \& Libraries Journal, 21(2): 45-53.

Hildreth, S. and Sullivan, M. 2015. Rising to the challenge: re-envisioning public libraries. Journal of Library Administration, 55(8): 647-657. DOl:10.1080/01930826.2015.1085247.

International Federation of Library Associations and Institutions (IFLA) Public Libraries Section. n.d. Public libraries support development through access to information. [Online]. https://www.ifla.org/files/assets/hq/topics/librariesdevelopment/documents/public-libraries-brief.pdf (11 July 2021).

Jiyane, G.V., Mugwisi, T. and Moyane, S.P. 2016. Market orientation as a strategy for service delivery in public libraries: a case study of the northern region in Kwazulu-Natal, South Africa. Mousaion, 34(4): 59-80. DOI:10.25159/00272639/1086.

Johnson, C.A. 2012. How do public libraries create social capital? A preliminary investigation into relationship. Library and Information Science Journal, 34(1): 52-62.

Johnson, C.A. 2015. Social capital and library and information science research: definitional chaos or research enterprise? Information Research, 20(4). [Online]. http://informationr.net/ir/20-4/paper690.html\#.X6Ruwm5uJjo (04 November 2020).

Latimer, K. 2007. Users and public space: what to consider when planning library space. In IFLA library building guidelines: developments and reflections. K. Latimer. and H. Niegaard, H., Eds. Munich: K.G. Saur 68-82.

Lor, P., van Helden, P. and Bothma, T.J.D. 2005. Developing a GIS-based inventory of South Africa's public libraries: the public and community libraries inventory of South Africa (PaCLISA) project. South African Journal of Library and Information Science, 71(3): 268-274.

Mantzaris, E. 2014. Public procurement, tendering and corruption: realities, challenges and tangible solutions. African Journal of Public Affairs, 7(2): 67-79.

Meyer, H.W.J. 2010. Training needs of library general workers: part 2: challenges facing the public library sector in South Africa. South African Journal of Library and Information Science, 76(2): 141-152.

Mnkeni-Saurombe, N. 2010. Impact of the 2009 economic recession on public/ community library services in South Africa: perceptions of librarians from the Metropolitan Municipality of Tshwane. Mousaion, 28(1): 89-105.

Mnkeni-Saurombe, N. and Zimu, N. 2015. Towards tackling inequalities in South Africa: the role of community libraries. Information Development, 31(1): 40-52.

Mohan, V.V. 2002. The information super-markets in the context of community information services. In Libraries and Information Studies in retrospect and prospects: Essays in honour of Prof D.T. Kalia. Volume 1. J.L. Sardana, Ed. New Delhi: Concept Publishing Company.

Mojapelo, S.M. 2017. Challenges faced by libraries in a democratic South Africa: a case of three community libraries in Limpopo Province. Information Development. DOI:10.1177/0266666917712337.

Mojapelo, S.M. and Fourie, J. 2014. Library and information resources in rural schools of Limpopo Province: a small study. Mousaion, (32)2: 124-149.

Mojapelo. S.M. 2020. The internet access and use in public libraries in Limpopo Province, South Africa. Public Library Quarterly, 39(3): 265-282. DOI:10.1080/01616846.2019.1622980.

Mokgaboki, S.N. 2002. Extending community library and information services to rural areas: the challenges that lie ahead. South African Journal of Libraries and Information Science, 68(1): 78-79.

Mostert, B.J. 1998. Community libraries: the concept and its application - with particular reference to South African community library system. International Information and Library Review, 30: 71-85.

Mostert, B.J. and Vermeulen, W.M. 1998. Community libraries: the concept and its application by the Pinetown public library. South African Journal of Library and Information Science, 66(1): 10-22.

Mthembu, M. 2019. Job requirements and challenges of LIS graduates in public libraries: a literature review. Library Philosophy and Practice (e-journal), 2772. [Online]. https://digitalcommons.unl.edu/libphilprac/2772 (19 April 2020).

National Education Policy Investigation. 1992. Library and information services: report of the NEPI library and information services research group. Cape Town: Oxford University Press/NECC

Nkondo, M., Brown, A., Dick, A., Hart, G., Molawa, S., Nassimbeni, M., Seleti, Y. and Teffo, L.J. 2014. The Library and Information Services (LIS) Transformation Charter. Pretoria: Department of Arts and Culture and the National Council for Library and Information Services (NCLIS). [Online]. http://www.dac.gov.za/sites/default/files/Final\%20draft_\%20LIS\%20Transformation\%20Charter.pdf (27 March 2015).

Nkondo, M., Hart, G. and Nassimbeni M. 2018. National policy for library and information services in South Africa. Pretoria: Department of Arts and Culture and the National Council for Library and Information Services. [Online]. https://www.nlsa.ac.za/condgrant/images/PDF/Draft-4-Final-14-March-2.pdf (13 July 2021).

Okiy, R.B. 2003. Information for rural development: challenge for Nigerian rural public libraries. Library Review, 52(3): $126-131$.

Osborne, R. 2004. From outreach to equity: innovative models of library policy and practice. Chicago: American Library Association. 
Pacy, A. 2014. Newspapers in the digital age: a study in how public library patrons read the news. Proceedings of the World Library and Information Congress: 81st IFLA General Conference and cast Assembly. 15-21 August 2015. Cape Town, South Africa. [Online]. https://www.ifla.org/files/assets/newspapers/Geneva_2014/s6-pacy-en.pdf (17 April 2020).

Patel, N., Skarzynski K. and Nassimbeni, M. 2015. Improving people's lives: measuring Harare public library's contribution to individual and community wellbeing. Proceedings of the World Library and Information Congress: 81 st IFLA General Conference and Assembly. 15-21 August 2015. Cape Town, South Africa. [Online] http://library.ifla.org/1240/1/088-patel-en.pdf.

Ralebipi-Simela, R. 2015. Strategic positioning of the National Library of South Africa (NLSA) as a change agent in social cohesion and nation building. Paper presented at IFLA WLIC 2015 - Cape Town, South Africa in Session 200 National Information and Library Policy SIG with National Libraries.

Raseroka, K.H., 1986. Relevant library services in developing countries. IFLA Journal, 12: 288-291.

Real, B., Bertot, J.C. and Jaeger, P.T. 2014. Rural public libraries and digital inclusion: issues and challenges. Information Technology and Libraries, 33(1): 6-24. DOI:10.6017/ital.v33i1.5141.

Reid, H. and Howard, V. 2016. Connecting with community: the importance of community engagement in rural public library systems. Public Library Quarterly, 35(3): 188-202.

Russell, S.E. and Huang, J. 2012. Rural libraries and communities: providing better services through creation of social capital. World Libraries, 20(1). [Online]. https://worldlibraries.dom.edu/index.php/worldlib/article/view/150 (04 November 2020).

Troknya, M. 2014. Challenges of a rural library. Public Libraries Online. 17 October. [Online]. http://publiclibrariesonline.org/ 2014/10/challenges-of-a-rural-library/ (21 July 2018).

Uzoigwe, C.U. and Chinwendu CA. 2017. Assessment of state government support to public library in Enugu State from 2010-2016. Samaru Journal of Information Studies, 17(1): 80-94.

Van der Walt, S. and du Plessis, T. 2010. Age diversity and the aging librarian in academic libraries in South Africa. South African Journal of Libraries and Information Science. 76(1). DOI:10.7553/76-1-81.

Van Helden, P and Lor, P.J. 2002. Public and community libraries inventory of South Africa: PaCLISA final report. Pretoria: National Library of South Africa.

Wishart, E. 2012. Libraries and information provision for African relief. Reading \& Writing, 3(1): 1-4. 